\title{
PENGEMBANGAN MODEL PENERIMAAN TEKNOLOGI INTERNET OLEH PELAJAR DENGAN MENGGUNAKAN KONSEP TECHNOLOGY ACCEPTANCE MODEL (TAM)
}

\author{
I Made Agus Ana Widiatmika dan Dana Indra Sensuse
}

Fakultas Ilmu Komputer, Universitas Indonesia, Depok, Indonesia

\begin{abstract}
Abstrak
Teknologi internet mulai diterima dan digemari dikalangan pelajar. Pelajar menggunakan fasilitas internet untuk membantu mereka dalam penyelesaian tugas sekolah. Tulisan ini menggunakan Technology Acceptance Model (TAM) untuk membangun model penerimaan teknologi internet di kalangan pelajar. Penelitian ini melibatkan 5 variabel endogen dan mengikutsertakan 4 variabel eksogen. Metode analisis yang digunakan adalah generalized least square (GLS) dan menggunakan polychoric correlation matrix dan asymptotic covariance matrix sebagai data tambahan. Tesis ini melibatkan 15 hipotesis yang mewakili hubungan antara variablevariabel yang ada. Pengujian hipotesis dilakukan untuk mendapatkan dan membuktikan model penerimaan teknologi internet yang komprehensif. Model penerimaan teknologi internet yang diperoleh bisa memberikan gambaran indikator-indikator yang harus diperhatikan dan menjadi hal yang bisa dikembangkan untuk penelitian lebih lanjut.
\end{abstract}

\section{Kata kunci : -}

\section{Pendahuluan}

Munculnya sebuah teknologi baru, khususnya di bidang teknologi informasi komunikasi akan selalu menghasilkan reaksi pada diri penggunanya. Reaksi dapat berupa penerimaan teknologi baru itu, atau bahkan penolakan akan hadirnya teknologi baru itu. Tidak terbendungnya teknologi masuk ke dalam proses bisnis (dalam kasus ini dunia pendidikan), maka perlu diketahui sejauh mana tingkat penerimaan teknologi tersebut oleh para pelajar.

Teknologi internet sebagai suatu media informasi yang informatif, komunikatif, dan terkini memiliki daya jangkau yang sangat luas. Teknologi internet bahkan dapat dikatakan hampir tak terbatas. Munculnya internet mampu memberikan kemudahan kepada manusia pada umumnya dan pelajar sebagai salah satu akademisi pendidikan pada khususnya, dapat memberikan perubahan dalam proses kehidupannya. Kehadiran internet akan memberikan jawaban ketika waktu sudah dianggap mahal (time is money). Berkomunikasi jarak jauh bisa menggunakan fasilitas $e$-mail, yang real time.

Tulisan ini menjelaskan pengembangan sebuah disain model untuk mengukur penerimaan teknologi internet oleh pelajar. Model ini didisain menjadi alat untuk mempelajari asimilasi aplikasi berbasiskan internet dan penyebaran teknologi dari organisasi ke konsumen. Perkembangan yang berarti telah dibuat pada sepuluh tahun terakhir dalam menjelaskan dan memprediksi user acceptance teknologi informasi. Secara menyeluruh, sebagian teori dan pengetahuan yang mendukung dikumpulkan untuk TAM (Technology Acceptance Model) [1]. Banyak penelitian telah menemukan bahwa TAM adalah sebuah model yang secara konsisten menjelaskan sebagian besar ragam (variance) dalam menggunakan tujuan dan tingkah laku, diantara sebuah variasi teknologi-teknologi. Penelitian juga menemukan bahwa TAM mampu menandingi dengan baik modelmodel alternative seperti TRA (Theory of Reasoned Action) dan TPB (Theory of Planned Behavior) (Mathieson, 1991; Sun, 2003).

\subsection{Permasalahan}

Terkait dengan tingkat penerimaan pelajar terhadap kehadiran teknologi internet, penulis mengidentifikasi adanya permasalahan yang dapat dijadikan dasar penelitian ini, yaitu:

1. Bagaimana model penerimaan teknologi internet yang baik bagi para pelajar ?

2. Faktor-faktor apakah yang saling berpengaruh terhadap tingkat penerimaan teknologi internet bagi para pelajar?

Indikator-indikator apa yang mempengaruhi tingkat penerimaan teknologi internet di kalangan pelajar?

\subsection{Tujuan}

Tujuan dari penulisan ini adalah: 
1. Menguji model penerimaan teknologi internet oleh pelajar dengan menggunakan konsep TAM

2. Membawa secara bersama-sama beberapa faktor eksternal yang telah diuji sebelumnya, menuju model yang komprehensif dan meneliti hubungan antara variabel di dalam TAM dan memprediksi tingkat penerimaan teknologi internet di kalangan pelajar

\section{Tinjauan Pustaka}

Pada penulisan ini, kami fokus pada ruang lingkup pembelajaran mengenai peneriman pengguna terhadap teknologi internet.

\subsection{Internet}

Internet dapat dirumuskan sebagai sekumpulan besar komputer dalam suatu jaringan yang tergabung secara bersama-sama sehingga banyak pengguna dapat berbagi sumber daya mereka secara luas (William, 1999). Adanya internet memungkinkan komputer untuk saling berhubungan satu sama lainnya dan memiliki kemampuan untuk mengirimkan data, baik berupa data tersetruktur maupun data tidak tersetruktur. Dapat dikatakan juga, internet merupakan suatu jaringan komputer yang saling terkoneksi dengan jaringan komputer yang lainnya ke seluruh penjuru dunia (Kiato, 1989).

\subsection{Technology Acceptance Model (TAM)}

Techonology Acceptance Model (TAM) adalah sebuah adaptasi dari TRA untuk memodelkan pengguna penerimaan sistem informasi [1]. Penerapan teknologi baru dalam organisasi akan berpengaruh terhadap keseluruhan organisasi, terutama pada sumber daya manusianya yang menjadi faktor pengendali organisasi.

Davis [1] menyebutkan bahwa tingkat penerimaan pengguna teknologi informasi ditentukan oleh enam pembangun, yaitu: variabel dari luar (external variable), persepsi pengguna terhadap kemudahan (perceived ease of use), persepsi pengguna terhadap manfaat (perceived usefulness), sikap dalam menggunakan (attitude toward using), perilaku untuk menggunakan (behavioral intention to use), dan pemakaian nyata (actual system usage).

\section{Metodologi Penelitian}

\subsection{Pengumpulan Data}

Data yang berhasil dikumpulkan akan diolah dan dianalisis untuk mendapatkan hasil penelitian. Penelitian ini menggunakan metode pengumpulan data menggunakan penyebaran kuisioner. Metode ini membutuhkan biaya yang relatif sedikit, namun

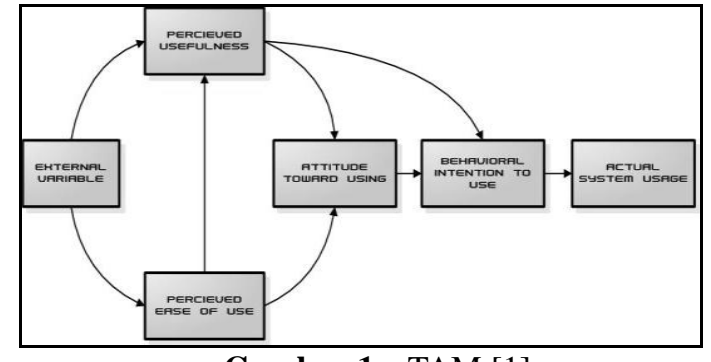

Gambar 1. TAM [1]

juga harus diakui mempunyai kelemahan berupa rendahnya response rate (Scheaffer et al., 1990). Kuisioner ini diberikan secarang langsung kepada responden yaitu siswa sekolah menengah atas, untuk mengatasi rendahnya response rate.

\subsubsection{Kuisioner}

Kuisioner berisikan daftar pernyataan yang disusun oleh penulis untuk mengetahui bagaimana pengaruh antara konstruk (1) jenis kelamin (gender), (2) pengalaman menggunakan internet (experience using the internet), (3) kompleksitas dalam menggunakan internet (complexity using the internet), dan (4) sukarela dalam menggunakan internet (voluntariness), (5) persepsi pengguna terhadap kemudahan menggunakan internet (perceived ease of use), (6) persepsi pengguna terhadap manfaat menggunakan internet (perceived usefulness), (7) sikap dalam menggunakan internet (attitude toward using), (8) perhatian untuk menggunakan internet (behavioral intention to use), dan (9) pemakaian internet (actual system usage) dari responden terhadap penerimaan teknologi internet di kalangan pelajar sekolah menengah atas.

\subsection{Model Persamaan Struktural}

Penerapan model persamaan struktural mengikuti prosedur umum seperti spesifikasi model, identifikasi, estimasi, uji kecocokan, dan respisifikasi. Hair et al., (1998) membagi tahapan dalam model persamaan struktural menjadi 8 langkah, yaitu: (1) mengembangkan model secara teoritis atau konseptualisasi model; (2) menyusun diagram jalur (path diagram); (3) menerjemahkan diagram jalur menjadi persamaan struktural (spesifikasi model); (4) identifikasi model; (5) estimasi parameter; (6) mengevaluasi atau penilaian model fit; (7) modifikasi model; dan (8) validasi silang model. Berikut uraian masing-masing langkah model persamaan struktural:

1. Mengembangkan Model Secara Teoritis

Tahapan ini berhubungan dengan pengembangan hipotesis sebagai dasar dalam menghubungkan variabel laten dengan variabel laten lainnya dan juga dengan indikatornya. Spesifikasi model secara garis 
Tabel 1. Variabel Laten Endogen dan Indikatornya

\begin{tabular}{|c|c|c|}
\hline $\begin{array}{l}\text { Variabel Laten } \\
\text { Endogen }\end{array}$ & & Indikator \\
\hline \multirow{6}{*}{$\begin{array}{c}\text { Perceived Ease } \\
\text { of Use of the } \\
\text { Internet } \\
{[2]}\end{array}$} & $\mathrm{Y} 1$ & $\begin{array}{l}\text { Belajar menggunakan internet } \\
\text { mudah bagi saya }\end{array}$ \\
\hline & $\mathrm{Y} 2$ & $\begin{array}{l}\text { Saya mudah mendapatkan sesuatu } \\
\text { yang saya butuhkan dari internet }\end{array}$ \\
\hline & $\mathrm{Y3}$ & $\begin{array}{l}\text { Interaksi saya dengan internet jelas } \\
\text { dan mudah dipahami }\end{array}$ \\
\hline & $\mathrm{Y} 4$ & $\begin{array}{l}\text { Saya fleksibel berinteraksi dengan } \\
\text { internet }\end{array}$ \\
\hline & Y5 & $\begin{array}{l}\text { Mudah bagi saya untuk menjadi } \\
\text { ahli menggunakan internet }\end{array}$ \\
\hline & Y6 & Internet mudah digunakan \\
\hline \multirow{6}{*}{$\begin{array}{c}\text { Perceived } \\
\text { Usefulness of the } \\
\text { Internet } \\
(\text { Sun, 2003) }\end{array}$} & Y7 & $\begin{array}{l}\text { Menggunakan internet bisa } \\
\text { mempercepat penyelesaian tugas } \\
\text { sekolah }\end{array}$ \\
\hline & $\mathrm{Y} 8$ & $\begin{array}{l}\text { Menggunakan internet bisa } \\
\text { meningkatkan kinerja sebagai } \\
\text { pelajar }\end{array}$ \\
\hline & Y9 & $\begin{array}{l}\text { Menggunakan internet bisa } \\
\text { memudahkan saya mengerjakan } \\
\text { dan menyelesaikan tugas sekolah }\end{array}$ \\
\hline & Y10 & $\begin{array}{l}\text { Menggunakan internet bisa } \\
\text { meningkatkan pengetahuan di } \\
\text { sekolah }\end{array}$ \\
\hline & Y11 & $\begin{array}{l}\text { Menggunakan internet bisa } \\
\text { meningkatkan efektivitas di sekolah }\end{array}$ \\
\hline & Y12 & $\begin{array}{l}\text { Saya merasakan internet } \\
\text { bermanfaat bagi saya di sekolah }\end{array}$ \\
\hline \multirow{4}{*}{$\begin{array}{l}\text { Attitude Toward } \\
\text { Using of the } \\
\text { Internet } \\
\text { (Davis, 2003) }\end{array}$} & Y13 & $\begin{array}{l}\text { Saya senang berinteraksi dengan } \\
\text { internet }\end{array}$ \\
\hline & Y14 & $\begin{array}{l}\text { Menggunakan internet memberikan } \\
\text { kenikmatan bagi saya }\end{array}$ \\
\hline & Y15 & $\begin{array}{l}\text { Saya menikmati menggunakan } \\
\text { internet }\end{array}$ \\
\hline & Y16 & $\begin{array}{l}\text { Menggunakan internet } \\
\text { membosankan saya }\end{array}$ \\
\hline \multirow{5}{*}{$\begin{array}{c}\text { Behavioral } \\
\text { Intention to Use } \\
\text { of the Internet } \\
\text { (Taylor dan Todd, } \\
\text { 1995) }\end{array}$} & Y17 & $\begin{array}{l}\text { Saya selalu mencoba menggunakan } \\
\text { internet untuk membantu } \\
\text { mengerjakan tugas, dengan fitur- } \\
\text { fitur ada }\end{array}$ \\
\hline & Y18 & $\begin{array}{l}\text { Saya selalu mencoba menggunakan } \\
\text { internet sesering mungkin untuk } \\
\text { meningkatkan pengetahuan }\end{array}$ \\
\hline & Y19 & $\begin{array}{l}\text { Saya membuat jadwal kapan } \\
\text { menggunakan internet dikemudian } \\
\text { hari }\end{array}$ \\
\hline & Y20 & $\begin{array}{l}\text { Saya bermaksud terus } \\
\text { menggunakan internet di kemudian } \\
\text { hari }\end{array}$ \\
\hline & Y21 & $\begin{array}{l}\text { Saya mengharapkan bisa terus } \\
\text { menggunakan internet di kemudian } \\
\text { hari }\end{array}$ \\
\hline \multirow[t]{3}{*}{$\begin{array}{l}\text { Actual Using of } \\
\text { the Internet } \\
\text { (Davis, 2003) }\end{array}$} & Y22 & $\begin{array}{l}\text { Setiap kali ke sekolah, saya selalu } \\
\text { menyempatkan untuk mengakses } \\
\text { internet }\end{array}$ \\
\hline & Y23 & $\begin{array}{l}\text { Saya mengakses internet hampir } \\
\text { setiap hari }\end{array}$ \\
\hline & Y24 & $\begin{array}{l}\text { Setiap kali melakukan akses } \\
\text { internet, sekurang-kurangnya saya } \\
\text { habiskan waktu selama } 15 \text { menit }\end{array}$ \\
\hline
\end{tabular}

Tabel 2. Variabel Laten Eksogen dan Indikatornya

\begin{tabular}{|c|c|c|}
\hline $\begin{array}{l}\text { Variabel Laten } \\
\text { Endogen }\end{array}$ & & Indikator \\
\hline $\begin{array}{c}\text { Gender } \\
\text { (Gefen dan } \\
\text { Straub, 1997) }\end{array}$ & $\mathrm{X} 1$ & Laki-Laki atau Perempuan \\
\hline \multirow{2}{*}{$\begin{array}{c}\text { Experience } \\
\text { Using the } \\
\text { Internet } \\
\text { (Szakna, 1996) }\end{array}$} & $\mathrm{X} 2$ & $\begin{array}{l}\text { Saya sangat berpengalaman } \\
\text { menggunakan internet }\end{array}$ \\
\hline & $\mathrm{X} 3$ & $\begin{array}{l}\text { Belum begitu lama menggunkan } \\
\text { internet }\end{array}$ \\
\hline \multirow{3}{*}{$\begin{array}{l}\text { Perceived } \\
\text { Complexity } \\
\text { Using the } \\
\text { Internet } \\
\text { (Chau dan } \mathrm{Hu}, \\
2001)\end{array}$} & $\mathrm{X} 4$ & $\begin{array}{l}\text { Menggunakan internet menghabiskan } \\
\text { waktu banyak untuk menyelesaikan } \\
\text { tugas }\end{array}$ \\
\hline & $\mathrm{X} 5$ & $\begin{array}{l}\text { Ketika saya menggunakan internet, } \\
\text { saya kesulitan untuk menyatukan } \\
\text { hasilnya dengan tugas saya }\end{array}$ \\
\hline & $\mathrm{X} 6$ & $\begin{array}{l}\text { Menggunakan internet membuat } \\
\text { komputer mudah terserang virus dan } \\
\text { kehilangan data }\end{array}$ \\
\hline \multirow{3}{*}{$\begin{array}{l}\text { Voluntariness } \\
\text { Using the } \\
\text { Internet } \\
\text { (Sun dan } \\
\text { Zhang, 2003) }\end{array}$} & $\mathrm{X} 7$ & $\begin{array}{l}\text { Menggunakan internet seperlunya, } \\
\text { sepanjang berhubungan dengan tugas } \\
\text { saya }\end{array}$ \\
\hline & $\mathrm{X} 8$ & $\begin{array}{l}\text { Saya tidak membutuhkan } \\
\text { menggunakan internet untuk tugas } \\
\text { sekolah saya }\end{array}$ \\
\hline & & $\begin{array}{l}\text { Meskipun internet dapat meningkatkan } \\
\text { efektivitas dalam menyelesaikan tugas, } \\
\text { tetapi saya tidak membutuhkannya }\end{array}$ \\
\hline
\end{tabular}

besar dijalankan dengan menspesifikasikan model pengukuran serta menspesifikasikan model struktural. Spesifikasi model pengukuran meliputi aktivitas mendefinisikan variabel-variabel laten, mendefinisikan variabel-variabel teramati, dan mendefinisikan hubungan antara variabel laten dengan variabel teramati. Spesifikasi model struktural dilakukan dengan mendefinisikan hubungan kausal di antara variabel-variabel laten.

\section{Menyusun Diagram Alur}

Diagram jalur dikembangkan sebagai metode untuk mempelajari pengaruh (efek) secara langsung dan secara tidak langsung dari variabel bebas (independen/eksogen variable) terhadap variabel terikat (dependen/endogen variable). Diagram jalur digunakan untuk menelaah hubungan antara model kausal yang telah dirumuskan peneliti atas dasar pertimbangan teoritis dan pengetahuan tertentu. Hubungan kausal selain didasarkan pada data, juga didasarkan pada pengetahuan, perumusan hipotesis dan analisis logis, sehingga dapat dikatakan analisis jalur dapat digunakan untuk menguji seperangkat hipotesis kausal serta menafsirkan hubungan tersebut. Satu diagram jalur akan membantu di dalam menginterpretasikan hubungan yang dihipotesiskan. Model teoritis yang telah dibangun kemudian digambarkan ke dalam bentuk diagram jalur. Biasanya hubungan-hubungan kausal dinyatakan dalam bentuk persamaan. 


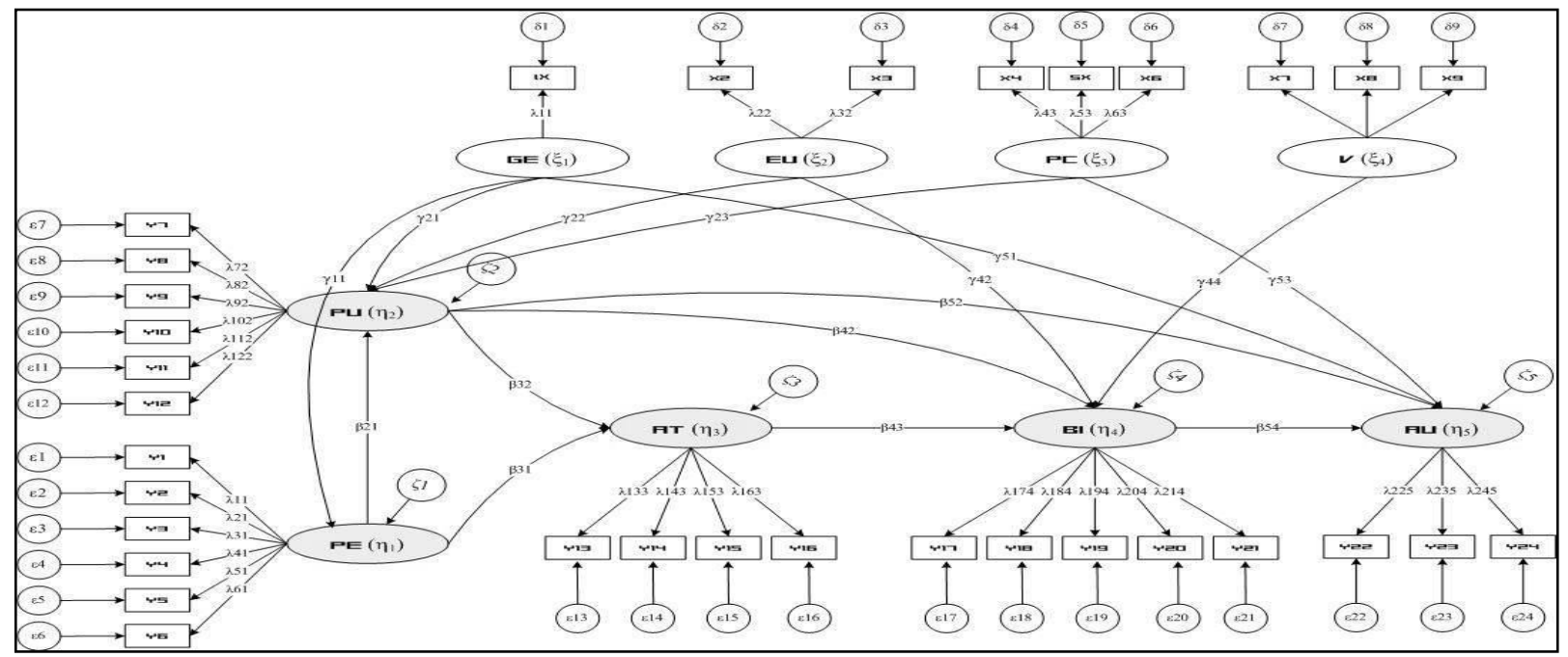

Gambar 2. Diagram Alur Model Penerimaan Internet oleh Pelajar

3. Menerjemahkan Diagram Alur menjadi Persamaan

Structural Equation Modelling (SEM) memperkenalkan 2 jenis model, yaitu model persamaan struktural dan model persamaan pengukuran.

- Persamaan Struktural dan Kesalahan Struktural Model struktural menggambarkan hubunganhubungan yang ada diantara variabel laten. Bentuk persamaan struktural dan kesalahan struktural dalam penelitian ini adalah:

$P E=\gamma_{11} G E+\zeta_{1}$

$P U=\beta_{21} P E+\gamma_{21} G E+\gamma_{22} E U+\gamma_{23} P C+\zeta_{2}$

$A T=\beta_{31} P E+\beta_{32} P U+\zeta_{3}$

$B I=\beta_{42} P U+\beta_{43} A T+\gamma_{42} E U+\gamma_{44} V+\zeta_{4}$

$A U=\beta_{52} P U+\beta_{54} B I+\gamma_{51} G E+\gamma_{53} P C+\zeta_{5}$

- Persamaan Pengukuran dan Kesalahan Pengukuran

Persamaan model pengukuran menggambarkan hubungan variabel laten dengan variabel-variabel teramati atau variabel indikator.

Bentuk persamaan model pengukuran dan kesalahan pengukuran adalah:

Variabel eksogen Gender:

$X_{1}=\lambda_{11} G E+\delta_{1}$

Variabel eksogen Experience Using the Internet:

$X_{2}=\lambda_{22} E U+\delta_{2}$

$X_{3}=\lambda_{32} E U+\delta_{3}$

Variabel eksogen Perceived Complexity Using the Internet:

$X_{4}=\lambda_{42} P C+\delta_{4}$

$X_{5}=\lambda_{52} P C+\delta_{5}$

$X_{6}=\lambda_{63} P C+\delta_{3}$
Variabel eksogen Voluntariness:

$X_{7}=\lambda_{73} V+\delta_{7}$

$X_{8}=\lambda_{83} V+\delta_{8}$

$X_{9}=\lambda_{94} V+\delta_{9}$

Variabel eksogen Perceived Ease of Use of the Internet:

$Y_{1}=\lambda_{11} P E+\varepsilon_{1}$

$Y_{2}=\lambda_{21} P E+\varepsilon_{2}$

$Y_{3}=\lambda_{31} P E+\varepsilon_{3}$

$Y_{4}=\lambda_{41} P E+\varepsilon_{4}$

$Y_{5}=\lambda_{51} P E+\varepsilon_{5}$

$Y_{6}=\lambda_{61} P E+\varepsilon_{6}$

Variabel endogen Perceived Usefulness of the Internet:

$Y_{7}=\lambda_{72} P U+\varepsilon_{7}$

$Y_{8}=\lambda_{82} P U+\varepsilon_{8}$

$Y_{9}=\lambda_{92} P U+\varepsilon_{9}$

$Y_{10}=\lambda_{102} P U+\varepsilon_{10}$

$Y_{11}=\lambda_{112} P U+\varepsilon_{11}$

$Y_{12}=\lambda_{122} P U+\varepsilon_{12}$

Variabel endogen Attitude Toward Using of the Internet:

$Y_{13}=\lambda_{133} A T+\varepsilon_{13}$

$Y_{14}=\lambda_{143} A T+\varepsilon_{14}$

$Y_{15}=\lambda_{153} A T+\varepsilon_{15}$

$Y_{16}=\lambda_{163} A T+\varepsilon_{16}$

Variabel endogen Behavioral Intention to Use of the Internet:

$Y_{17}=\lambda_{174} B I+\varepsilon_{17}$ 


$$
\begin{aligned}
& Y_{18}=\lambda_{184} B I+\varepsilon_{18} \\
& Y_{19}=\lambda_{194} B I+\varepsilon_{19} \\
& Y_{20}=\lambda_{204} B I+\varepsilon_{20} \\
& Y_{21}=\lambda_{214} B I+\varepsilon_{21} \\
& \text { Variabel endogen Actual Usage of the Internet: } \\
& Y_{22}=\lambda_{225} A U+\varepsilon_{22} \\
& Y_{23}=\lambda_{235} A U+\varepsilon_{23} \\
& Y_{24}=\lambda_{245} A U+\varepsilon_{24}
\end{aligned}
$$

\section{Identifikasi Model}

Informasi yang diperoleh dari data, diuji untuk menentukan apakah cukup untuk mengestimasi parameter dalam model. Tahapan identifikasi model dimaksudkan untuk menjaga agar model yang dispesifikasikan bukan merupakan model yang underidentified atau unidentified. Model yang memenuhi syarat untuk dianalisis hanyalah model yang overidentified [3].

\section{Estimasi Parameter}

Joreskog dan Sorbom (1993, 1996) dan Joreskog (2002) berpendapat bahwa data ordinal (data yang digunakan pada penelitian ini) harus diperlakukan sebagai data ordinal dan tidak boleh diperlakukan sebagai data continu. Metode analisis yang akan digunakan adalah Generalized Least Squre (GLS) dan menggunakan polychoric correlation dan data tambahan asymptotic covariance matrix.

Analisis model persamaan struktural dengan data ordinal, data mentah tidak dapat digunakan untuk melakukan analisis. Data mentah tersebut harus dikonversi kedalam bentuk polychoric correlation. Polychoric correlation merupakan matriks korelasi yang seluruh variabel memiliki skala ordinal dan juga diperlakukan sebagai data ordinal.

Joreskog (1996, 2002) menganjurkan tidak menggunakan metode Maximum Likeliood dalam menggunakan SEM dengan data ordinal, karena akan menghasilkan estimasi parameter dan model fit yang bias. Metode yang digunakan pada penelitian ini adalah Generalized Least Squre (GLS), yang diproksikan dengan penggunaan data asymptotic covariance matrix.

\section{Penilaian Model Fit}

Tahapan ini ditujukan untuk mengevaluasi derajat kecocokan atau Goodness of Fit (GOF) antara data dengan model. Suatu model diakatakan fit apabila kovarian matriks suatu model (model-based covariance matrix) adalah sama dengan kovarian matriks data (data observed covariance matrix).

Hair et al. (1996) evaluasi terhadap GOF model dilakukan melalui beberapa tingkatan, yaitu: 1) kecocokan keseluruhan model (overall model fit), 2) kecocokan model pengukuran (measurement model fit), dan 3) kecocokan model struktural (structural model fit).

\section{Modifikasi Model}

Modifiksi model dilakukan atau diperlukan karena tidak fitnya hasil yang diperoleh pada tahapan keenam. Namun segala modifikasi model (meskipun sedikit) harus selalu berdasarkan teori yang mendukung. Pertimbangan untuk memodifikasi model umumnya dilakukan jika model sudah dapat diterima. Modifikasi model dilakukan untuk memperbaiki penjelasan secara teoritis.

\section{Validasi Silang}

Tahapan ini merupakan tahapan yang terakhir, yaitu menguji fit-tidaknya model terhadap suatu data baru (atau validasi sub-sampel yang diperoleh melalui prosedur pemecahan sampel). Validasi silang ini penting apabila terdapat modifikasi yang substansial yang dilakukan terhadap model asli yang dilakukan pada langkah ketujuh.

\subsection{Analisis Uji Kecocokan}

Model Persamaan Struktural memiliki tujuan utama dalam analisisnya. Tujuan pertama adalah untuk menentukan apakah model plausible (masuk akal) atau fit, atau dengan bahasa yang lebih mudah, apakah model "benar" berdasarkan suatu data yang dimiliki. Sedangkan tujuan yang kedua adalah untuk menguji berbagai hipotesis yang telah dibangun sebelumnya.

Dalam konteks model fit, model fit dapat ditentukan dengan meminimalkan perbedaan antara sample covariance matrix dan implied covariance matrix. Sample covariance matrix adalah kovarian yang diperoleh melalui observasi (data kuisioner), sedangkan implied covariance matrix adalah matrik kovarian yang diperoleh berdasarkan model. Beberapa hal yang dilakukan pada model persamaan struktural (SEM), sebagai berikut:

\section{Ragam (Variance) dan Kovarian (Covariance)}

Ragam atau Variance mengukur penyimpangan data dari nilai rata-rata (mean) suatu sampel, dan merupakan suatu ukuran untuk variabel-variabel metrik. Secara sistematis variance adalah rata-rata perbedaan kuadrat antara tiap-tiap observasi dan mean. Sehingga, variance adalah nilai kuadrat dari standar deviasi. Suatu variabel pasti memiliki variance dan variance tersebut selalu positif (jika nol, bukan variabel tetapi konstanta).

Covariance menunjukkan hubungan linear yang terjadi antara dua variabel. Jika suatu variabel 
memiliki hubungan linear yang positif, maka covariance adalah positif. Jika hubungan antara variabel tersebut adalah berlawanan (negatif), maka covariance adalah negatif. Jika tidak terdapat hubungan antara variabel tersebut, maka nilai covariance adalah nol.

2. Indikator untuk Menilai Model Fit

Evaluasi suatu model fit merupakan salah satu tahapan pada model persamaan struktural (SEM). Bollen dan Long (1993), MacCallum (1990), Mulaik et al. (1989), dan Steiger (1990) memberikan suatu pandangan dan rekomendasi mengenai indikatorindikator model fit. Secara keseluruhan Goodness of Fit dari suatu model dapat dinilai berdasarkan beberapa ukuran fit berikut:

- Chi-Square dan Probabilitas

- Goodness of Fit Indices (GFI)

- Adjusted Goodness of Fit Index (AGFI)

- Parsimony Goodness of Fit Index (PGFI)

- Root Mean Square Error of Approximation (RMSEA)

- Expected Cross Validation Index (ECVI)

- Akaike's Information Criterion (AIC) dan (CAIC)

- Fit Index (NFI)

3. Metod Estimasi

Model persamaan struktural (SEM) umumnya melibatkan 7 metode estimasi yang sering digunakan untuk mengestimasi parameter dari suatu model, yaitu; (1) Instrumental Variabel (IV), (2) Two Stage Least Square (TSLS), (3) Unweighted Least Square (ULS), (4) Generalized Least Square (GLS), (5) Generally Weighted Least Square (GWLS), (6) Diagonally Weighted Least Square (GWLS), dan (7) Maximum Likelihood (ML).

\section{Asumsi Model Persamaan Struktural}

Uji asumsi model persamaan struktural adalah kegiatan yang dilakukan sebelum menguji kelayakan sebuah model persamaan struktural. Pengujian meliputi pengujian terhadap data observasi agar sesuai dengan asumsi-asumsi dalam model persamaan struktural. Model persamaan struktural mengharuskan data dalam keadaan normal. LISREL memberikan alternatif lain untuk mengatasi data yang belum dalam keadaan normal, yaitu dengan menambahkan input berupa matrix correlation dan matrix asymptotic.

\section{Input Data}

Berdasarkan pada kategori data yang dimiliki, LISREL membagi data menjadi data continu dan data ordinal. Data continu adalah data yang dapat memiliki nilai apa saja dan tidak memiliki kategorikategori yang berurutan. Sedangkan data ordinal adalah data yang memiliki kategori berurutan. Penelitian ini menggunakan data ordinal dengan skala Likert (1-7).

Joreskog dan Sorbom (1993) menyatakan bahwa variabel ordinal bukan variabel kontinu dan tidak seharunya diperlakukan sebagai data kontinu. Jorekog dan Sorbom juga menyatakan bahwa karena variabel-variabel ini tidak memiliki metrik, maka nilai mean, varian, dan kovarian variabel tersebut tidak berarti. Joreskog dan Sorbom menganjurkan penggunaan polychoric correlation sebagai input data apabila data memiliki skala ordinal.

\section{Signifikansi Parameter}

Signifikansi parameter memberikan gambaran besar kecilnya pengaruh variabel yang satu dengan variabel yang lainnya. LISREL memberikan 3 nilai acuan yang dapat digunakan untuk menilai signifikansi antara satu variabel dengan variabel yang lain. Koefisien regresi, standar error dan nilai $t$ merupakan informasi yang digunakan pada penelitian ini untuk menunjukkan signifikansi antara satu dengan variabel yang lain. Standar error digunakan untuk mengukur ketepatan estimasi parameter. Nilai $t$ diperoleh melalui perbandingan antara nilai estimasi dengan standar error.

$$
t=\frac{\text { Estimasi Regresi }}{\text { Standar Error }}
$$

Pada penelitian ini akan menggunakan level signifikansi sebesar 0,05 , sehingga nilai $|t|$ yang diharapkan adalah lebih dari 1,96.

\section{Analisis dan Pembahasan}

\subsection{Analisis Data dan Model Persamaan Struktural}

Model teoritis untuk keperluan penelitian ini dibuat berlandaskan pada konsep Technology Acceptance Model (TAM) yang dikembangkan oleh Davis [4].

Model teoritis yang telah dibangun, selanjutnya ditrasformasi ke dalam bentuk diagram jalur (path diagram) yang menggambarkan persamaan struktural antar variabel-variabel yang ada, termasuk kesalahan (error) masing-masing (Gambar 1).

\subsubsection{Estimasi Parameter Model}

Joreskog dan Sorbom $(1993,1996)$ dan Joreskog (2002) berpendapat bahwa data ordinal (data yang digunakan pada penelitian ini) harus diperlakukan sebagai data ordinal dan tidak boleh diperlakukan sebagai data continu. Metode analisis yang akan digunakan adalah Generalized Least Squre (GLS) dan menggunakan polychoric correlation dan data 
tambahan asymptotic covariance matrix.

Tabel 3. Ringkasan Uji Kecocokan

\begin{tabular}{|l|c|}
\hline \multicolumn{1}{|c|}{ Goodness of Fit Statistics } & Nilai \\
\hline Degrees of Freedom & 49 \\
\hline Chi-Square & 174.33 \\
\hline RMSEA & 0.034 \\
\hline ECVI & 3.56 \\
\hline AIC Model & 1009.71 \\
\hline Independence AIC & 5097.45 \\
\hline Saturated AIC & 1122.00 \\
\hline CAIC Model & 2218.94 \\
\hline Independence CAIC & 5252.68 \\
\hline Saturated CAIC & 3760.82 \\
\hline NFI & 0.92 \\
\hline PGFI & 0.66 \\
\hline AGFI & 0.91 \\
\hline GFI & 0.93 \\
\hline CFI & 0.98 \\
\hline
\end{tabular}

Analisis model persamaan struktural dengan data ordinal, data mentah tidak dapat digunakan untuk melakukan analisis. Data mentah tersebut harus dikonversi kedalam bentuk polychoric correlation. Polychoric correlation merupakan matriks korelasi yang seluruh variabel memiliki skala ordinal dan juga diperlakukan sebagai data ordinal.

Joreskog (1996, 2002) menganjurkan tidak menggunakan metode Maximum Likeliood dalam menggunakan SEM dengan data ordinal, karena akan menghasilkan estimasi parameter dan model fit yang bias. Metode yang digunakan pada penelitian ini adalah Generalized Least Squre (GLS), yang diproksikan dengan penggunaan data asymptotic covariance matrix.

Output persamaan pengukuran (measurement equations) menginformasikan estimasi mengenai hubungan antara indikator dengan variabel latennya. Output persamaan struktural (structural equations) menginformasikan nilai estimasi hubungan antara variabel laten eksogen dengan variabel laten endogen atau antara variabel laten endogen dengan variabel laten endogen lainnya.

\subsubsection{Penilaian Model Fit}

Konsep persamaan struktural memberikan tiga jenis uji kecocokan model yang dapat dilakukan, yaitu uji kecocokan model secara menyeluruh (overall model fit), uji kecocokan model pengukuran (measurement model fit), dan uji kecocokan model struktural (structural model fit).

1. Uji Kecocokan Model Secara Menyeluruh (Overall Model Fit)

Menilai model fit adalah sesuatu yang kompleks dan memerlukan perhataian besar. Konsep SEM dalam menilai model fit tidak hanya bergantung pada satu indeks fit. Tetapi sebaiknya mempertimbangkan seluruh indeks fit. Hasil pengujian overall fit secara umum model yang diusulkan dapat dikatakan fit. Berikut ringkasan hasil penilain model fit:

\section{Chi-Square}

Model pada penelitian ini memiliki nilai chisquare sebesar 174.33 dengan 49 degree of freedom. Probabilitas chi-square adalah signifikan $(\mathrm{P}=0.39)$ yang berarti bahwa model dapat dikatakan fit.

Indikator goodness of fit berikutnya adalah rasio perbandingan antara nilai chi-square dengan degree of freedom. Rasio $\chi^{2} / d f$ model penelitian ini adalah $174.33 / 49=3.56$. Hasil tersebut lebih rendah dari cut-off model fit yang disarankan oleh Wheaton (1977), yaitu 5 dan lebih tinggi sesuai yang dianjurkan oleh Carmines dan Melver (1981) yaitu 2. Sehingga dapat diambil kesimpulan bahwa dengan mengendalikan kompleksitas model (yang diproksikan dengan jumlah degrees of freedom) sebenarnya model sudah memiliki fit yang baik.

\section{RMSEA}

RMSEA model adalah sebesar 0.034. Hal tersebut mengindikasikan bahwa model sudah fit dan tidak termasuk pada kategori penolakan. Juga 90 Percent Confidence Interval for RMSEA = (0.032; 0.037) mengindikasikan bahwa nilai RMSEA tersebut memiliki ketepatan yang baik.

\section{ECVI}

Expected Cross Validation Index pada model penelitian ini adalah sebesar 3.56, sedangkan ECVI for Independence Model $=17.05$. Nilai ECVI lebih rendah dari ECVI for Independence Model. Sehingga dapat disimpulkan bahwa model baik untuk direplikasi untuk penelitian berikutnya.

\section{AIC dan CAIC}

Model pada kategori ini dikatakan baik karena nilai AIC lebih rendah dari pada independence dan saturated AIC dan CAIC juga lebih rendah daripada independence dan saturated CAIC.

\section{NFI}

Suatu model dikatakan fit apabila memiliki nilai NFI (Normed Fit Index) lebih besar dari 0.9. Model pada penelitian ini menunjukkan bahwa nilai NFI di atas yang disarankan, yaitu 0.92 sehingga mengindikasikan model fit.

\section{CFI}

Suatu model dikatakan baik apabila memiliki nilai CFI yang mendekati 1 dan 0.9 adalah batas model fit (Bentler, 1990). Model pada penelitian ini menghasilkan nilai CFI sebesar 0.98 sehingga 
dapat dikatakan bahwa model adalah fit.

Tabel 4. Uji Validitas

\begin{tabular}{|c|c|c|c|}
\hline $\begin{array}{l}\text { VARIABEL } \\
\text { LATEN }\end{array}$ & $\begin{array}{l}\text { INDI- } \\
\text { KATOR }\end{array}$ & $\begin{array}{l}\text { SIGNIFIKANS } \\
\text { I PENGARUH }\end{array}$ & $\begin{array}{l}\text { NILA } \\
\text { I } t\end{array}$ \\
\hline \multirow{6}{*}{$\begin{array}{l}\text { Perceived } \\
\text { Ease of Use } \\
\text { the Internet } \\
\quad(\mathrm{PE})\end{array}$} & Y1 & 0.92 & - \\
\hline & Y2 & 0.76 & 15.72 \\
\hline & Y3 & 0.70 & 13.95 \\
\hline & $\mathrm{Y} 4$ & 0.38 & 3.75 \\
\hline & Y5 & 0.64 & 12.01 \\
\hline & Y6 & 0.33 & 6.62 \\
\hline \multirow{6}{*}{$\begin{array}{l}\text { Perceived } \\
\text { Usefulness } \\
\text { of Use the } \\
\text { Internet } \\
\text { (PU) }\end{array}$} & $\mathrm{Y7}$ & 1.20 & - \\
\hline & Y8 & 0.91 & 55.58 \\
\hline & Y9 & 1.10 & 71.19 \\
\hline & Y10 & 0.59 & 40.75 \\
\hline & Y11 & 1.06 & 61.64 \\
\hline & Y12 & 0.73 & 51.71 \\
\hline \multirow{4}{*}{$\begin{array}{c}\text { Attitude } \\
\text { Toward (AT) }\end{array}$} & $\mathrm{Y} 13$ & 0.87 & - \\
\hline & Y14 & 1.01 & 38.93 \\
\hline & Y15 & 1.03 & 35.52 \\
\hline & Y16 & 1.21 & 38.82 \\
\hline \multirow{5}{*}{$\begin{array}{l}\text { Behavioral } \\
\text { Intention } \\
\text { (BI) }\end{array}$} & Y17 & 0.74 & - \\
\hline & $\mathrm{Y} 18$ & 0.46 & 18.61 \\
\hline & Y19 & 0.41 & 8.60 \\
\hline & Y20 & 0.52 & 21.86 \\
\hline & Y21 & 0.74 & 24.71 \\
\hline \multirow{3}{*}{$\begin{array}{l}\text { Actual } \\
\text { Ussage } \\
\text { (AU) }\end{array}$} & $\mathrm{Y} 22$ & 0.87 & - \\
\hline & Y23 & 0.93 & 13.33 \\
\hline & Y24 & 0.32 & 3.29 \\
\hline $\begin{array}{c}\text { Gender } \\
\text { (GE) }\end{array}$ & $\mathrm{X} 1$ & 0.38 & - \\
\hline \multirow{2}{*}{$\begin{array}{l}\text { Experience } \\
\text { Using (EU) }\end{array}$} & $\mathrm{X} 2$ & 0.86 & 15.27 \\
\hline & X3 & 0.75 & 12.25 \\
\hline \multirow{3}{*}{$\begin{array}{l}\text { Perceived } \\
\text { Complexity } \\
\text { (PC) }\end{array}$} & $\mathrm{X} 4$ & 0.80 & 28.35 \\
\hline & $\mathrm{X} 5$ & 0.39 & 5.13 \\
\hline & X6 & 0.64 & 2.69 \\
\hline \multirow{3}{*}{$\begin{array}{l}\text { Voluntarines } \\
\text { (V) }\end{array}$} & $\mathrm{X} 7$ & 0.37 & 2.55 \\
\hline & $\mathrm{X} 8$ & 0.40 & 2.26 \\
\hline & $\mathrm{X} 9$ & 0.31 & 4.59 \\
\hline
\end{tabular}

2. Uji Kecocokan Model Pengukuran (Measurement Model Fit)

Hasil pengujian overall model fit secara umum dapat diterima, maka setiap konstruk dapat dievaluasi secara terpisah dengan melakukan: 1) uji validitas, yaitu melihat signifikansi indikator standard loading, dan 2) uji reliabilitas, yaitu menilai reliabilitas konstruk.

Mengevaluasi model pengukuran harus berfokus pada hubungan-hubungan antara variabel laten dengan indikatornya (variabel manifes). Tujuan dalam mengevaluasi model pengukuran ini adalah untuk menentukan validitas dan reliabilitas indikator-indikator dari suatu konstruk.
Tabel 5. Uji Reliabilitas

\begin{tabular}{|c|c|c|c|}
\hline $\begin{array}{l}\text { VARIABEL } \\
\text { LATEN }\end{array}$ & $\begin{array}{l}\text { INDI- } \\
\text { KATOR }\end{array}$ & $\mathrm{R}^{2}$ & $\begin{array}{c}\text { Error } \\
\text { Variance }\end{array}$ \\
\hline \multirow{12}{*}{$\begin{array}{l}\text { Perceived } \\
\text { Ease of Use } \\
\text { the Internet } \\
\quad(\mathrm{PE})\end{array}$} & $\mathrm{Y} 1$ & 0.68 & 0.40 \\
\hline & $\mathrm{Y} 2$ & 0.61 & 0.37 \\
\hline & Y3 & 0.53 & 0.44 \\
\hline & $\mathrm{Y} 4$ & 0.59 & 0.62 \\
\hline & Y5 & 0.47 & 0.46 \\
\hline & Y6 & 0.17 & 0.53 \\
\hline & Y7 & 0.72 & 0.56 \\
\hline & Y8 & 0.59 & 0.57 \\
\hline & Y9 & 0.75 & 0.39 \\
\hline & Y10 & 0.37 & 0.61 \\
\hline & Y11 & 0.64 & 0.64 \\
\hline & Y12 & 0.53 & 0.47 \\
\hline \multirow{4}{*}{$\begin{array}{c}\text { Attitude } \\
\text { Toward (AT) }\end{array}$} & Y13 & 0.66 & 0.40 \\
\hline & Y14 & 0.75 & 0.35 \\
\hline & Y15 & 0.68 & 0.48 \\
\hline & Y16 & 0.77 & 0.45 \\
\hline \multirow{5}{*}{$\begin{array}{l}\text { Behavioral } \\
\text { Intention } \\
\text { (BI) }\end{array}$} & Y17 & 0.67 & 0.27 \\
\hline & Y18 & 0.34 & 0.42 \\
\hline & Y19 & 0.76 & 0.41 \\
\hline & $\mathrm{Y} 20$ & 0.48 & 0.29 \\
\hline & Y21 & 0.62 & 0.33 \\
\hline \multirow{3}{*}{$\begin{array}{c}\text { Actual } \\
\text { Ussage (AU) }\end{array}$} & Y22 & 0.63 & 0.44 \\
\hline & $\mathrm{Y} 23$ & 0.76 & 0.27 \\
\hline & $\mathrm{Y} 24$ & 0.27 & 0.51 \\
\hline Gender (GE) & $\mathrm{X} 1$ & 0.61 & 0.24 \\
\hline \multirow{2}{*}{$\begin{array}{l}\text { Experience } \\
\text { Using (EU) }\end{array}$} & $\mathrm{X} 2$ & 0.78 & 0.21 \\
\hline & $\mathrm{X} 3$ & 0.50 & 0.56 \\
\hline \multirow{3}{*}{$\begin{array}{l}\text { Perceived } \\
\text { Complexity } \\
\text { (PC) }\end{array}$} & $\mathrm{X} 4$ & 0.90 & 0.07 \\
\hline & $\mathrm{X5}$ & 0.64 & 0.19 \\
\hline & $\mathrm{X6}$ & 0.68 & 0.59 \\
\hline \multirow{3}{*}{$\begin{array}{c}\text { Voluntarines } \\
\text { (V) }\end{array}$} & $\mathrm{X} 7$ & 0.31 & 0.26 \\
\hline & $\mathrm{X} 8$ & 0.49 & 0.23 \\
\hline & $\mathrm{X} 9$ & 0.92 & 0.27 \\
\hline
\end{tabular}

\section{Validitas}

Uji validitas merupakan suatu uji yang bertujuan untuk menentukan kemampuan suatu indikator dalam mengukur variabel laten tersebut. Validitas suatu indikator sebenarnya dapat dievaluasi dengan signifikansi pengaruh antara suatu variabel laten dengan indikatornya.

Uji validitas dilakukan dengan memeriksa dua jenis nilai, yaitu nilai $t$ dan nilai $\lambda$ (signifikansi pengaruh). Ukuran yang direkomendasikan untuk nilai $t$ adalah diluar interval -1.96 dan 1.96 . Sedangkan nilai $|\lambda|$ (signifikansi pengaruh) dianjurkan lebih besar dari 0.30. Berikut uji validitas indikator untuk masing-masing variabel laten ditunjukkan di table 4.

Hasil kedua nilai ( $t$ dan $\lambda$ ) dapat ditarik kesimpulan bahwa seluruh variebl indikator berhubungan dengan masing-masing konstruk di dalam model secara signifikan, atau dengan kata lain seluruh variabel indikator memiliki kemampuan untuk mewakili masing-masing konstruk dalam model. 


\section{Reliabilitas}

Reliabilitas dari suatu indikator dapat dilakukan dengan memperhatikan nilai squared multiple correlations $\left(\mathrm{R}^{2}\right)$ dari indikator. $\mathrm{R}^{2}$ menjelaskan mengenai seberapa besar proporsi varians indikator yang dijelaskan oleh variabel laten (sisanya dijelaskan oleh measurement error).

Melihat hasil uji composite reliability untuk masing-masing variabel laten, dapat dikatakan masing-masing indikator memberikan ukuran yang reliabel untuk masing-masing variabel latennya.

3. Uji Kecocokan Model Pengukuran

(Measurement Model Fit)

Menguji persaman struktural pada penelitian ini kembali menggunakan faktor squared multiple correlations $\left(\mathrm{R}^{2}\right)$. Seberapa sesar variabel laten menjelaskan atau seberapa besar kontribusi variabel laten terhadap variabel laten yang lainnya akan dijelaskan oleh squared multiple correlations $\left(\mathrm{R}^{2}\right)$.

Tabel 6. Uji Kecocokan Pengukuran

\begin{tabular}{|c|c|}
\hline $\begin{array}{c}\text { Persamaan Struktural } \\
\text { untuk Variabel }\end{array}$ & $\begin{array}{c}\text { Squared Multiple } \\
\text { Correlations }\left(\mathbf{R}^{\mathbf{2}}\right)\end{array}$ \\
\hline PE & 0.74 \\
\hline PU & 0.95 \\
\hline AT & 0.86 \\
\hline BI & 0.89 \\
\hline AU & 0.64 \\
\hline
\end{tabular}

Hasil uji di atas dapat dijelaskan bahwa dari lima persamaan struktural kelima-limanya mempunyai nilai squared multiple correlations $\left(\mathrm{R}^{2}\right)$ yang signifikan yaitu lebih besar dari 0.60. Signifikan yang besar berarti juga variabel-variabel tersebut mempunyai pengaruh yang besar terhadap variabel yang lain.

Persamaan struktural yang pertama adalah Perceived Ease (PE) yang dipengaruhi oleh Gender (GE). Persamaan struktural pertama menghasilkan nilai squared multiple correlations $\left(\mathrm{R}^{2}\right)$ sebesar 0.74. Berarti variabel laten Gender (GE) berkontribusi sebesar $74 \%$ pada Perceived Ease (PE).

Persamaan struktural yang kedua adalah Perceived Usefulness (PU) yang dipengaruhi oleh Perceived Ease (PE), Experience Using (EU), Gender (GE) dan Perceived Complexity (PC). Persamaan struktural kedua menghasilkan nilai squared multiple correlations $\left(\mathrm{R}^{2}\right)$ sebesar 0.95 . Berarti variabel laten Perceived Ease (PE), Experience Using (EU), Gender (GE) dan Perceived Complexity (PC) berkontribusi sebesar $95 \%$ pada Perceived Usefulness (PU).

Persamaan struktural yang ketiga adalah Attitude Toward (AT) yang dipengaruhi oleh
Perceived Ease (PE) dan Perceived Usefullnes (PU). Persamaan struktural ketiga menghasilkan nilai squared multiple correlations $\left(\mathrm{R}^{2}\right)$ sebesar 0.86. Berarti variabel laten Perceived Ease (PE) dan Perceived Usefullnes (PU) berkontribusi sebesar $86 \%$ pada Attitude Toward (AT).

Persamaan struktural yang keempat adalah Behavioral Intention (BI) yang dipengaruhi oleh Perceived Usefullness (PU), Attitude Toward (AT), Experience Using (EU), dan Voluntariness (V). Persamaan struktural keempat menghasilkan nilai squared multiple correlations $\left(\mathrm{R}^{2}\right)$ sebesar 0.89 . Berarti variabel laten Perceived Usefullness (PU), Attitude Toward (AT), Experience Using (EU), dan Voluntariness (V) berkontribusi sebesar $89 \%$ pada Behavioral Intention (BI).

Persamaan struktural yang kelima adalah Actual Usage (AU) yang dipengaruhi oleh Perceived Usefullness (PU), Behavioral Intention (BI), Gender (GE) dan Perceived Complexity (PC). Persamaan struktural ini menghasilkan nilai squared multiple correlations $\left(\mathrm{R}^{2}\right)$ sebesar 0.64. Berarti variabel laten Perceived Usefullness (PU), Behavioral Intention (BI), Gender (GE) dan Perceived Complexity (PC) berkontribusi sebesar $64 \%$ pada Actual Usage (AU).

Secara keseluruhan pengujian model persaman struktural menunjukkan hasil yang cukup signifikan secara statistik, sehingga dapat disimpulkan bahwa model tersebut memiliki tingkat kecocokan yang cukup baik dalam menggambarkan hubungan antara konstruk yang dibentuk dengan variabel indikator yang mewakilinya.

\subsubsection{Pengujian Hipotesis}

Hipotesis-hipotesis yang dibangun dalam penelitian ini adalah:

H1 : Perceived Ease of Use of the Internet (PE) berpengaruh terhadap Perceived Usefulness of the Internet (PU)

H2 : Perceived Ease of Use of the Internet (PE) berpengaruh terhadap Attitude Toward Using of the Internet (AT)

H3 : Perceived Usefulness of the Internet (PU) berpengaruh terhadap Attitude Toward Using of the Internet (AT)

H4 : Perceived Usefulness of the Internet (PU) berpengaruh terhadap Behavioral Intention to Use the Internet (BI)

$\mathrm{H5}$ : Perceived Usefulness of the Internet (PU) berpengaruh terhadap Actual System Usage of the Internet (AU) 
H6 : Attitude Toward Using of the Internet (AT) berpengaruh terhadap Behavioral Intention to Use the Internet (BI)

H7 : Behavioral Intention to Use the Internet (BI) berpengaruh terhadap Actual System Usage of the Internet (AU)

H8 : Gender (GE) berpengaruh terhadap Perceived Ease of Use of the Internet (PE)

H9 : Gender (GE) berpengaruh terhadap Perceived Usefulness of the Internet (PU)

H10: Gender (GE) berpengaruh terhadap Actual System Usage of the Internet (AU)

H11: Experience Using the Internet (EU) berpengaruh terhadap Perceived Usefulness of the Internet (PU)

H12: Experience Using the Internet (EU) berpengaruh terhadap Behavioral Intention to Use the Internet (BI)

H13: Perceived Complexity Using the Internet (PC) berpengaruh terhadap Perceived Usefulness of the Internet (PU)

H14: Perceived Complexity Using the Internet (PC) berpengaruh terhadap Actual System Usage of the Internet (AU)

H15: Voluntariness (V) berpengaruh terhadap Behavioral Intention Usage of the Internet (BI)

Pengujian hipotesis penelitian dilakukan dengan menguji hubungan antar konstruk secara serentak. Berdasarkan kelima persamaan di atas, hipotesishipotesis yang ada dapat dikelompokkan ke dalam lima kelompok besar. Kelompok pertama yang mencerminkan penuangan persamaan (1) melibatkan hipotesis H8. Kelompok kedua dengan persamaan (2) melibatkan pengujian hipotesis $\mathrm{H} 1, \mathrm{H} 9, \mathrm{H} 11$, dan H13. Persamaan (3) membawa dua hipotesis yaitu H2 dan H3. Kelompok yang keempat dalam persamaan (4) melibatkan pengujian hipotesis $\mathrm{H} 4$, H6, H12, dan H15. Kelompok ke lima melibatkan hipotesis $\mathrm{H} 5$, H10, dan $\mathrm{H} 14$ dalam persamaan struktural yang ke (5).

Hipotesis pada penelitian ini melibatkan 15 hipotesis yang muncul dari variabel laten yang ada dan diuji pada penelitian ini. Setelah dilakukan uji hipotesis dari 15 hipotesis yang ada, menghasilkan kesimpulan 15 hipotesis diterima atau tidak ada hipotesis yang ditolak.

Pengujian terhadap hipotesis $\mathrm{H} 1$ dan $\mathrm{H} 2$ memberikan kesimpulan bahwa kedua hipotesis tersebut dapat diterima, yang berarti variabel laten persepsi kemudahan pelajar menggunakan internet (perceived ease of use of the internet) memiliki pengaruh positif yang signifikan terhadap persepsi manfaat yang dirasakan pelajar dalam menggunakan internet (perceived usefulness of the internet) dan persepsi tingkah laku pelajar dalam menggunakan internet (attitude toward using of the internet). Hal ini dapat diartikan bahwa semakin mudah yang dirasakan pelajar dalam menggunakan internet, semakin besar manfaat yang akan diterima pelajar akibat menggunakan internet. Begitu juga akan meningkatkan kenikmatan yang dirasakan pelajar dalam menggunakan internet. Pada pengujian ini pengaruh persepsi kemudahan pelajar dalam menggunakan internet lebih besar pengaruhnya terhadap persepsi manfaat yang dirasakan pelajar (dengan faktor loading 0.75) dibandingkan terhadap persepsi tingkah laku pelajar dalam menggunakan internet (dengan faktor loading 0.17). Hal ini sejalan dengan hasil penelitian Chau (1996) dan Davis et al. [1] yang melakukan penelitian tentang penggunaan teknologi internet. Kedua penelitian tersebut memiliki kesimpulan yang sama yaitu persepsi kemudahan menggunakan internet baik secara langsung berpengaruh terhadap persepsi manfaat yang dirasakan, dan mempunyai pengaruh secara tidak langsung mempengaruhi persepsi tingkah laku melalui persepsi kemudahan.

Pengujian terhadap hipotesis $\mathrm{H} 3, \mathrm{H} 4$, dan $\mathrm{H} 5$ memberikan kesimpulan bahwa kedua hipotesis tersebut dapat diterima, yang berarti persepsi manfaat yang dirasakan pelajar dalam menggunakan internet (perceived usefulness of the internet) mempunyai pengaruh positif yang signifikan terhadap tiga variabel laten yang lain. Ketiga variabel laten yang dipengaruhi tersebut adalah persepsi sikap pelajar (attitude toward using of the internet), persepsi prilaku atau kebiasaan pelajar dalam menggunakan internet (behavioral intention to use the internet) dan prilaku nyata pelajar menggunakan internet (actual system usage of the internet). Pada penelitian ini memberikan informasi bahwa persepsi manfaat yang dirasakan pelajar dalam menggunakan internet berturut turut dari yang paling besar mempunyai pengaruh terhadap persepsi prilaku atau kebiasaan pelajar dalam menggunakan internet (dengan faktor loading 1.37), yang kedua berpengaruh terhadap prilaku nyata pelajar menggunakan internet (dengan faktor loading 0.17) dan terakhir berpengaruh terhadap prilaku nyata pelajar menggunakan internet (dengan faktor loading 0.16). Hal ini sejalan dengan hasil penelitian yang dilakukan Iqbaria [5] yang menyatakan persepsi manfaat mempunya pengaruh yang kuat terhadap penggunaan teknologi internet pada perusahaan bisnis kecil. 
Pengujian terhadap hipotesis H6 memberikan kesimpulan bahwa hipotesis tersebut dapat diterima, yang bararti persepsi sikap pelajar dalam menggunakan internet (attitude toward using of the internet) mempunyai pengaruh positif yang signifikan terhadap persepsi prilaku atau kebiasaan pelajar dalam menggunakan internet (behavioral intention to use the internet). Penelitian ini memberikan informasi bahwa persepsi sikap pelajar dalam menggunakan internet memberikan faktor loading sebesar 0.26 terhadap persepsi kebiasaan pelajar dalam menggunakan internet. Hal tersebut juga dapat memberikan gambaran bahwa pengaruh persepsi sikap pelajar dalam menggunakan internet tidak begitu banyak terhadap kebiasaan pelajar dalam menggunakan internet. Hal ini sejalan dengan Taylor dan Tod (1995) yang menyatakan bahwa pengaruh persepsi sikap tidak begitu signifikan terhadap kebiasaan dalam menggunakan internet untuk pengguna yang sudah berpengalaman. Juga mengindikasikan bahwa pelajar pada penelitian ini sudah termasuk dalam sampel yang berpengalaman dalam menggunakan internet.

Pengujian terhadap hipotesis $\mathrm{H} 7$ memberikan kesimpulan bahwa hipotesis tersebut dapat diterima, yang berarti persepsi prilaku atau kebiasaan pelajar dalam menggunakan internet (behavioral intention to use the internet) berpengaruh signifikan terhadap penggunaan nyata teknologi internet oleh pelajar (actual system usage of the internet). Penelitian ini memberikan informasi bahwa persepsi prilaku atau kebiasaan pelajar dalam menggunakan internet dalam mempengaruhi penggunaan nyata teknologi internet oleh pelajar sebesar $48 \%$.

Pengujian terhadap hipotesis $\mathrm{H} 8, \mathrm{H} 9$, dan $\mathrm{H} 10$ memberikan kesimpulan bahwa hipotesis tersebut dapat diterima, yang artinya jenis kelamin (gender) mempunyai pengaruh yang signifikan terhadap persepsi kemudahan pelajar menggunakan internet (perceived ease of use of the internet) memiliki pengaruh yang signifikan terhadap persepsi manfaat yang dirasakan pelajar dalam menggunakan internet (perceived usefulness of the internet), dan penggunaan nyata teknologi internet oleh pelajar (actual system usage of the internet).

Pengujian terhadap hipotesis $\mathrm{H} 11$ dan $\mathrm{H} 12$ memberikan kesimpulan bahwa hipotesis tersebut dapat diterima, yang berarti persepsi pengalaman menggunkan internet (experience using the internet) mempunyai pengaruh yang signifikan terhadap persepsi manfaat yang dirasakan pelajar dalam menggunakan internet (perceived usefulness of the internet) dan persepsi prilaku atau kebiasaan pelajar dalam menggunakan internet (behavioral intention to use the internet). Penelitian ini menginformasikan bahwa persepsi pengalaman menggunakan internet (experience using the internet) berpengaruh secara positif terhadap persepsi persepsi manfaat yang dirasakan pelajar dalam menggunakan internet dan persepsi prilaku atau kebiasaan pelajar dalam menggunakan internet. Diantara kedua faktor yang dipengaruhi, persepsi manfaat yang dirasakan pelajar dalam menggunakan internet dipengaruhi lebih besar daripada persepsi prilaku atau kebiasaan pelajar dalam menggunakan internet. Hal ini sejalan dengan penelitian Venkatesh dan Moris [2] berpendapat bahwa pengalaman menggunakan internet akan semakin meningkat dengan berjalannya waktu, dan juga berdampak pada meningkatnya rasa menfaat dalam menggunakan internet.

Pengujian terhadap hipotesis $\mathrm{H} 13$ dan $\mathrm{H} 14$ memberikan kesimpulan bahwa hipotesis tersebut dapat diterima, yang berarti persepsi kesulitan menggunkan internet (complexity using the internet) mempunyai pengaruh negatif yang signifikan terhadap persepsi manfaat yang dirasakan pelajar dalam menggunakan internet (perceived usefulness of the internet) dan penggunaan nyata teknologi internet oleh pelajar (actual system usage of the internet). Penelitian ini juga memberikan gambaran bahwa, persepsi kesulitan memberikan pengaruh negatif terhadap persepsi manfaat dan penggunaan nyata teknologi internet oleh pelajar. Berarti semakin tinggi tingkat kesulitan pelajar dalam menggunakan internet semakin rendah manfaat yang dirasakan oleh pelajar, dan semakin jarang juga pelajar menggunakan internet. Thompson et al. (1991) juga berpendapat bahwa tingkat kesulitan menggunakan internet memiliki hubungan yang berlawanan dengan tingkat kemudahan dan penggunaan teknologi internet.

Pengujian terhadap hipotesis H15 memberikan kesimpulan bahwa hipotesis tersebut dapat diterima, artinya kebebasan menggunakan internet (voluntariness using the internet) mempunyai pengaruh positif yang signifikan terhadap persepsi prilaku atau kebiasaan pelajar dalam menggunakan internet (behavioral intention to use the internet). Semakin bebas yang dirasakan siswa dalam menggunakan internet (baik bebas dari segi waktu maupun bebas dari segi tujuan menggunakan internet), maka semakin meningkat frekuensi pelajar dalam menggunakan internet dan akan meningkatkan keinginan untuk terus menggunakan internet di kemudian hari.

\section{Kesimpulan}

Berdasarkan hasil penelitian tentang penerimaan teknologi internet oleh pelajar pada tingkat sekolah 
menengah atas, maka penulis dapat menyimpulkan beberapa hal sebagai berikut:

1. Hasil estimasi awal terhadap model yang dikembangkan sejak awal secara teoritis, dengan menggunakan hasil penelitian sebelumnya menunjukkan bahwa model sudah termasuk dalam kategori fit, sehingga penulis merasa tidak perlu untuk melalukan modifikasi model. Karena modifikasi yang dilakukan pada model yang sudah menunjukkan model fit yang baik, belum tentu akan memberikan hasil penelitian yang sama apabila digunakan pada sampel yang berbeda. Penulis merasa opsi modifikasi pada penelitian ini patut dihindari. Hal ini juga dapat mengindikasikan bahwa model yang digunakan pada penelitian ini sudah cocok dengan situasi dengan penulis mengambil data sampel yang mewakili populasi pelajar.

2. Penelitian ini melibatkan 15 hipotesis dan setelah melakukan uji hipotesis diperoleh hasil bahwa 15 hipotesis yang diuji menghasilkan kesimpulan hipotesis diterima. Kemudahan menggunakan internet memberikan pengaruh positif terhadap manfaat yang dirasakan oleh pelajar dan juga memberikan pengaruh positif terhadap tingkah laku atau kebiasaan pelajar dalam menggunakan internet. Manfaat yang dirasakan pelajar dalam menggunakan internet juga memberikan pengaruh yang positif terhadap tingkah laku atau sikap pelajar menggunakan internet, prilaku pelajar dalam menggunakan internet, dan penggunaan nyata teknologi internet oleh pelajar. Sikap pelajar dalam menggunakan internet seperti rasa senang yang diperoleh atau dirasakan pelajar ketika berinternet akan memberikan dampak yang positif pada peningkatan keinginan untuk menggunakan internet. Dengan munculnya kesenangan dalam menggunakan internet yang mendorong pelajar untuk selalu ingin mencoba berinternet, akan berpengaruh positif terhadap semakin lamanya waktu yang dihabiskan oleh pelajar untuk berinternet. Penelitian ini juga menarik kesimpulan bahwa jenis kelamin juga ikut serta mempunyai pengaruh pada manfaat yang diperoleh, kemudahan yang diperoleh, dan penggunaan internet. Semakin berpengalaman pelajar dalam menggunakan internet semakin besar rasa manfaat yang dirasakannya dan semakin besar rasa ingin selalu bisa menggunakan internet. Sebaliknya semakin besar tingkat kesulitan yang dihadapi oleh pelajar semakin rendah rasa manfaat yang dirasakan dan semakin jarang pelajar menggunakan internet. Kebebasan dalam menggunakan internet juga memberikan pengaruh positif terhadap perilaku pelajar dalam berinternet.

Kedua hasil di atas memberikan kesimpulan bahwa Technology Acceptance Model (TAM) yang diusulkan secara umum dapat dijadikan sebagai model penerimaan teknologi internet oleh pelajar khususnya pelejar sekolah menengah atas dengan fasilitas dan kondisi yang memenuhi. Model TAM pada penelitian ini menggunakan 9 variabel laten dengan 33 buah indikator sebagai variabel manifes.

\section{REFERENSI}

[1] Davis, F.D. "Perceived Usefulness, Perceived Ease of Use, and User Acceptance of Information Tecnology". MIS Quarterly, 13, 1989, pp. 319-340.

[2] Venkatesh, V. "Determinants of Perceived Ease of Use: Integrating Control, Intrinsic Motivation, and Emotion into the TAM" IS Research (11:4), pp. 342$365,2000$.

[3] Ghozali, Imam. Model Persamaan Struktural konsep \& Aplikasi dengan Program AMOS Ver. 5.0 Badan Penerbit Undip, Semarang, 2004.

[4] Davis, F.D. "User Acceptance of Imformation Technology: System Characteristics, User Perception, and Behavioral Impact". International Journal of Man Machine Studies, 38, 1993, pp. 475-487.

[5] Iqbaria, M, et.al. "Personal Computing Acceptence Factors in Small Firm: A Structural Equation Modelling”. MIS Quarterly, 21(3), 1997. 